\title{
Long term change in vegetation following herbi- cide control of larkspur
}

\author{
MICHAEL H. RALPHS
}

Author is rangeland scientist, USDAVARS Poisonous Plant Lab, 1150 E. 1400 N. Logan Utah, 84321 .

\begin{abstract}
Larkspur (Delphinium spp.) control can reduce cattle deaths on mountain rangelands, but vegetation cover must be maintained to protect watersheds from erosion. The objective of this study was to evaluate the long term impact of herbicides on larkspur control and cover of associated species. Duncecap larkspur (Delphisium occidentale S. Watts) near Oakley Ida., and tall larkspur (D. barbeyi Huth) near Manti Utah, were the target species. Picloram (4-amino-3,5,6-trichloro-2-pyridinecarboxylic acid) was applied at $1.1,2.2$, and $4.5 \mathrm{~kg}$ ae/ha; glyphosate $(\mathrm{N}$ (phosphonomethyl)glycine) was applied at $0.06,1.1$, and $2.2 \mathrm{~kg}$ ci/ha; and metsulfuron (1-IIII(4-methoxy-6-methyl-1,3,5-triazin2-yi)amine]carbonyl]amino]sulfonyllbenzoic acid) was applied at $0.035,0.07$, and $0.14 \mathrm{~kg}$ ailha. Picloram at $2.2 \mathrm{~kg} / \mathrm{ha}$ maintained long-term control of both larkspur species ( $80 \%$ ) when applied in the vegetative, bud, and flower growth stages. Total grass cover was higher on picloram plots than other treatments. Forb cover declined and bare ground was greater in picloram plots than ofler treatments at Manti. Metsulfuron controlled duncecap larkspur when applied in the vegetative stage. However, long-term control of tall larkspur at Manti declined as new tall larkspur seedlings established. Glyphosate controlled both larkspurs when applied in the vegetative and bud stages, but it allowed undesirable annual and rhizomatous forbs and shrubs to increase by the end of the study. Grass cover was lower on glyphosate plots than on other treatments. Bare ground was higher on glyphosate plots than other treatments at Oakley, but was intermediate at Manti.
\end{abstract}

Key Words: poisonous plant, Delphinium occidentale, Eciphizrizm barbeyi, picloram, metsulfuron, glyphosate.

Tall larkspurs (Delphinium spp.) are principal components of tall forb communities on mountain rangelands and occur in patches where snow drifis accumulate and provide additional soil moisture. Larkspur patches are common in mountain big sagebrush (Artemisia tridentata var vaseyana (Rybd) J. Bovin), aspen (Populus tremuloides Michx), and subalpine plant communities. Cattle deaths from larkspur poisoning can be significantly reduced by controlling patches of larkspur (Cronin and Nielsen 1979).

High mountain rangelands where larkspur occurs also have high value as watersheds (Ellison 1954). Thus, any larkspur control should not degrade watershed condition by reducing vegetation cover, or alter species composition to a lower seral stage that would accelerate erosion. The objective of this study was to document the long term effects of herbicides on larkspur control and associated species composition and cover.

\section{Methods}

Herbicide trials on duncecap ( $D$. occidentale S. Watts) and tall larkspur ( $D$. barbeyi Huth) were conducted to determine effective rates and timing of application. Ralphs et al. (1992) reported the change in larkspur density and associated species cover the first year after treatment. These plots were maintained for up to 5 years to determine the long term impact on larkspur density, species composition, foliar cover, and bare ground.

The duncecap larkspur study site was $32 \mathrm{~km}$ west of Oakley, Ida. at $2.500 \mathrm{~m}$ elevation in the mountain big sagebrush plant community. Duncecap larkspur dominated the site, and associated species included mountain brome (Bromus marginatus Nees ex Steud.), slender wheatgrass (Elymus trachycaulus (Link) Gould ex Shiners), and an assortment of small forbs.

The tall larkspur study site was $24 \mathrm{~km}$ east of Manti Utah at $3,200 \mathrm{~m}$ elevation in the subalpine zone. Pockets of Engelman spruce (Picea engelmannii Parry ex Engelm.) and currant thickets (Ribes montigenium McClatchie) were prevalent. The openings were dominated by tall larkspur, with slender wheatgrass, mountain brome, and letterman needlegrass (Stipa lettermanii Vasey) scattered throughout.

Density of tall larkspur plants at Manti was less than the density of duncecap larkspur at Oakley (1.3 vs 6.8 plants $/ \mathrm{m}^{2}$, respectively) but tall larkspur plants had more stalks and were more robust than duncecap larkspur. Foliar cover of larkspur was similar at both locations ( 33 vs $39 \%$ respectively).

Precipitation data were collected from weather stations near the sites. Winter accumulation as snow, and monthly precipitation during the growing season are presented in Table 1 . 
Table 1. Winter and monthly growing season precipitation. ${ }^{1}$

\begin{tabular}{|c|c|c|c|c|c|c|c|c|c|c|c|c|c|}
\hline & \multicolumn{6}{|c|}{ Oakley } & \multicolumn{7}{|c|}{ Manti } \\
\hline & 1088 & 1989 & 1990 & 1991 & 1992 & $\begin{array}{r}30 \mathrm{yr} \\
\text { avg. }\end{array}$ & 1988 & 1989 & 1990 & 1991 & 1992 & 1993 & $\begin{array}{l}52 \mathrm{yr} \\
\text { avg. }\end{array}$ \\
\hline & $=-$ & $\cdots$ & - & $\cdots$ & -- & $\ldots$ & $\ldots--c \mathrm{~cm}$ & $\ldots$ & $\ldots$ & - - & - - - & - & $\cdots$ \\
\hline \multicolumn{14}{|c|}{ Growing Season } \\
\hline June & 3 & 2 & 3 & 4 & 9 & 3 & 3 & 5 & 8 & 1 & 4 & 6 & 4 \\
\hline Sept. & 1 & 2 & 1 & 2 & 1 & 3 & 4 & 6 & 6 & 9 & 4 & 3 & 5 \\
\hline Total & 44 & 68 & 49 & 57 & 46 & 64 & 85 & 77 & 90 & 99 & 74 & 117 & 92 \\
\hline
\end{tabular}

$1 /$ Weather recording stations was $13 \mathrm{~km}$ north of the Manti site and $2 \mathrm{~km}$ south of the Oakley site at similar elevations.

\section{Application and Evaluation}

Picloram (4-amino-3,5,6-trichloro-2-pyridinecarboxylic acid) was applied at 1.1, 2.2 and $4.5 \mathrm{~kg}$ ae/ha; glyphosate (N-(phosphonomethyl)glycine) at $0.6,1.1$, and $2.2 \mathrm{~kg}$ aiha; metsulfuron (1[III(4-methoxy-6-methyl-1,3,5-triazin-2-yl)amine] carbonyl]amino]sulfonyl]benzoic acid) at $0.035,0.070$ and 0.140 $\mathrm{kg}$ ae/ha; and an untreated check plot was included. These treatments were applied when larkspur was in the vegetative, bud, and flower growth stages in 1988 and on separate plots in 1989. Plot size was 1.8 by $10 \mathrm{~m}$, and treatments were arranged in a randomized complete block design and replicated 3 times. Further details on the site and application were presented by Ralphs et al. (1992).

Larkspur density was determined by counting the number of larkspur plants in each plot prior to treatment, 1 year after treatment, then again in 1992 at Oakley and 1993 at Manti. The study was originally designed to last 5 years, but the plots at Oakley were read one year early because the rancher was anxious to apply the metsulfuron treatments throughout his allotment. Larkspur control was calculated as the percentage change in density from before treatment. Effective control was arbitrarily set at $80 \%$. Foliar cover of associated species was measured by the line point method. A tape was stretched the length of each plot and a sharpened rod was lowered at $15-\mathrm{cm}$ intervals. The plant or ground item first encountered by the rod was recorded. Percentage foliar cover or bare ground was calculated and expressed in the time periods described above.

Larkspur control and species cover data were analyzed separately for the 2 locations by analysis of variance (ANOVA). Trials (sprayed in 1988 and 1989), growth stages, and their interactions were tested by the replication within (trial $x$ stage) interaction. Herbicide treatment and its interaction with trial and stage was iested by the treatment $x$ replication within (trial $\times$ stage) interaction. Year of evaluation and its interaction with trial and stage was tested by the year $x$ replication within (trial $x$ stage) interaction. The year $x$ treatment, and the 3-way interactions with trial and stage were tested by the residual error. Data were transformed by arcsin prior to analysis, but the non-transformed means are presented in the tables. Mean separations of herbicide treatments were conducted using Least Significant Difference (LSD, $P<.05$ ). The differences in larkspur control between the first year after spraying and the end of the study for each treatment were determined by paired t-tests. Differences in cover of assaciated species between year 0,1 , and the end of the study were determined by LSD for each herbicide.

\section{Results}

\section{Larkspur Control \\ Oakley}

There was a significant main effect for year of evaluation $(P<.01)$. Overall control averaged $68 \%$ the first year after treatment, but increased to $78 \%$ by the end of the study. Duncecap larkspur density in the untreated check plot declined $17 \%$ in year 1 , and $44 \%$ by the end of the study (Table 2). This was probably due to the prolonged drought in the region (Table 1). There was no reinvasion or establishment of larkspur over the 4 year period.

Trends in the initial control were still apparent after 4 years. Duncecap larkspur control was greater when herbicides were applied in the vegetative stage (89\%) compared to application in the bud and flower stages (61 and 69\%, respectively). Picloram was effective over all growth stages, while glyphosate was less effective in the flower stage, and efficacy of metsulfuron declined in both the bud and flower stage.

\section{Manti}

There were also differences in control between years of evaluation at Manti $(P<.01)$. Overall control dropped from $63 \%$ the first year following treatment to $48 \%$ by the end of the study. The decline in control was mostly from the metsulfuron treatments (Table 2). Metsulfuron at $0.140 \mathrm{~kg} / \mathrm{ha}$ killed 95 and $89 \%$ of larkspur plants the first year after spraying in the vegetative and bud stage respectively (Table 2). However, control dropped to 55 and $19 \%$, respectively, by the end of the study. Metsulfuron killed the larkspur plants in the plots, but new larkspur plants germinated and established in both sets of plots that were treated in 1988 and 1989. New larkspur plants did not establish in the picloram or glyphosate plots, nor did they establish in any of the treatments at Oakley.

\section{Cover of Associated Species}

There were few differences in response of associated species between growth stages or application rates. Therefore, the cover means were pooled over growth stages and rates to illustrate the main effects of herbicides on the change in species composition over time. Where differences occurred between growth stages or herbicide rates, they will be discussed in the text. 
Table 2. Control of cuncecap and tall larkspur one year and five years after treatment in the vegetative, bud and flower stage of growth.

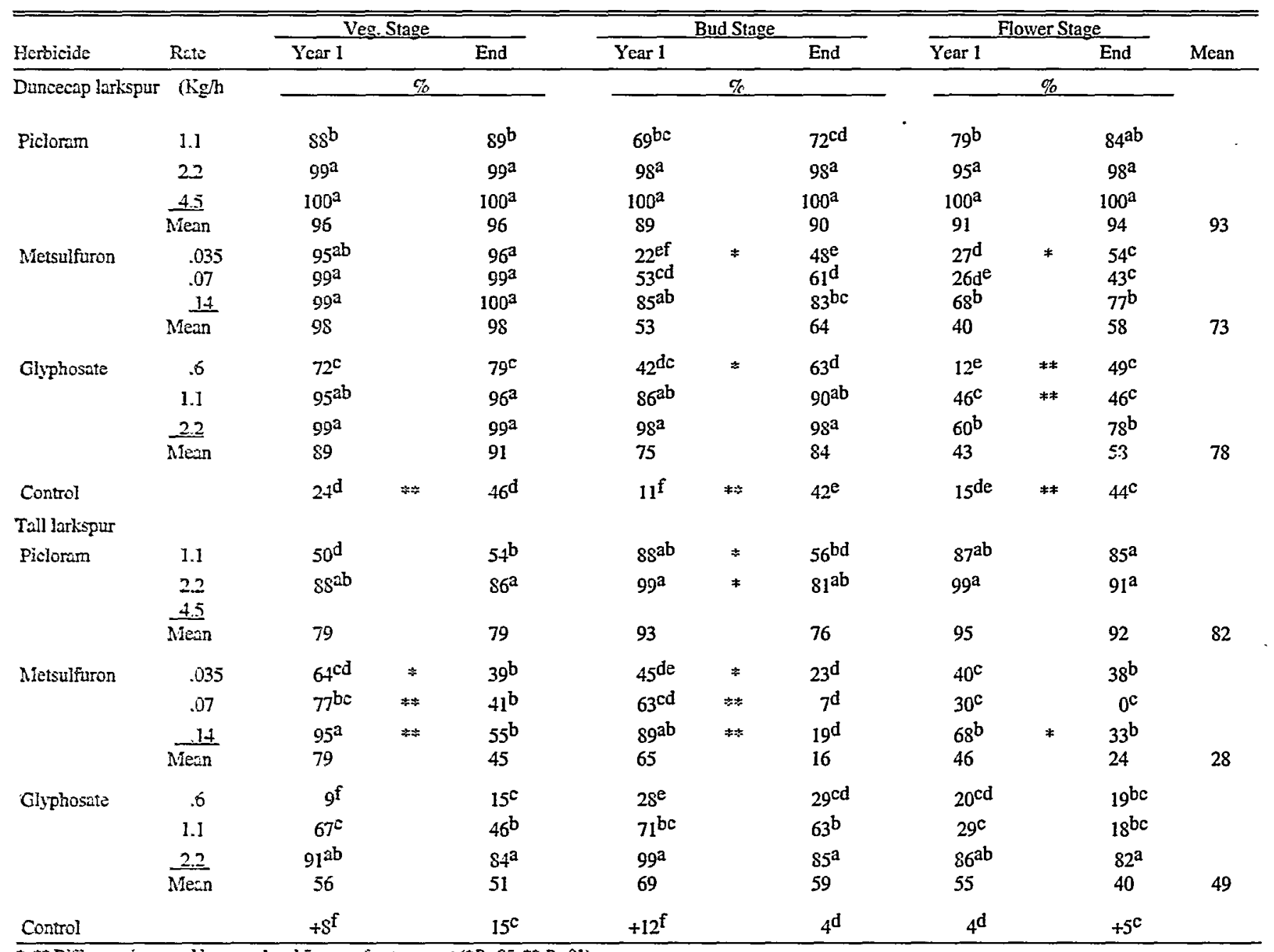

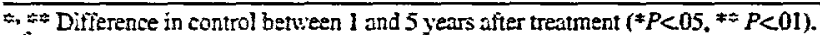

a-f hieans in the same colums. within larkspur species, not followed by the same letter are significantly different determined by LSD $(P<05)$.

\section{Oakley}

Forb cover declined the first year following treatment with picloram and metsulfuron (Fig. 1a). Forbs remained low on plots treated with picloram at the end of the study, but increased slightly on plots treated with metsulfuron. Forbs increased 3 to 4 fold in plots treated with glyphosate in year 1. Pine violet (Viola purpurea Kellog) and annual forbs such as knotweed (Polygonum erectum L) and tansy mustard (Descurainia pinnatta Walt.) contributed up to $20 \%$ of the cover. Forbs declined by the end of the study in the glyphosate plots, but remained higher than plots treated with the other herbicides. There was also a higher proportion of forbs when larkspur was sprayed in its vegetative stage with picloram or glyphosate $(5,1,1 \%$ for picloram; 11,8 , and $6 \%$ for glyphosate in the vegetative, bud and flower stage respecxively), indicaring that the forbs were less affected when sprayed early in the season.

Mountain big sagebrush increased in all treatments by the end of the study (Fig. Ib), but was much greater in plots treated with glyphosate at 1.1 and $2.2 \mathrm{~kg} / \mathrm{ha}$ (12 and 20\%, respectively). The greater amount of bare ground in these treatments in the early years apparently allowed sagebrush seedlings to establish.
Slender wheatgrass increased in plots treated with metsulfuron in year $1(27 \%)$, then declined to pretreatment levels by the end of the study (18\%) (Fig. 1c). Slender wheatgrass increased the first year in plots treated with picloram at 1.1 and $2.2 \mathrm{~kg} / \mathrm{ha}$ (29-30\% cover), but declined to $10 \%$ in the $4.5 \mathrm{~kg} / \mathrm{ha}$ treatment. This high level of picloram was detrimental to slender wheatgrass. Glyphosate reduced slender wheatgrass cover slightly (Fig. 1c). However, glyphosate at $2.2 \mathrm{~kg} / \mathrm{ha}$ reduced slender wheatgrass cover to $5 \%$ in year 1, but it increased to $10 \%$ by the end of the study. Slender wheatgrass was reduced to a greater extent when sprayed with glyphosate in larkspur's vegetative stage. At the end of the study, slender wheatgrass cover was highest (18-20\%) in the picloram and metsulfuron plots.

Letterman needlegrass cover in the picloram and metsulfuron treatments increased to 24 and $21 \%$, respectively, in year 1, but returned to pretreatment levels at the end of the study (14 and 11\%) (Fig. 1d). Glyphosate greatly reduced Letterman needlegrass, and its cover remained low at the end of the study (4\%).

Other grasses on site included Kentucky bluegrass (Poa pratensis L), onion grass (Melica bulbosa Geyer ex Port. \& Coult.), Idaho fescue (Festuca idahoensis Elmer), and great basin wildrye 

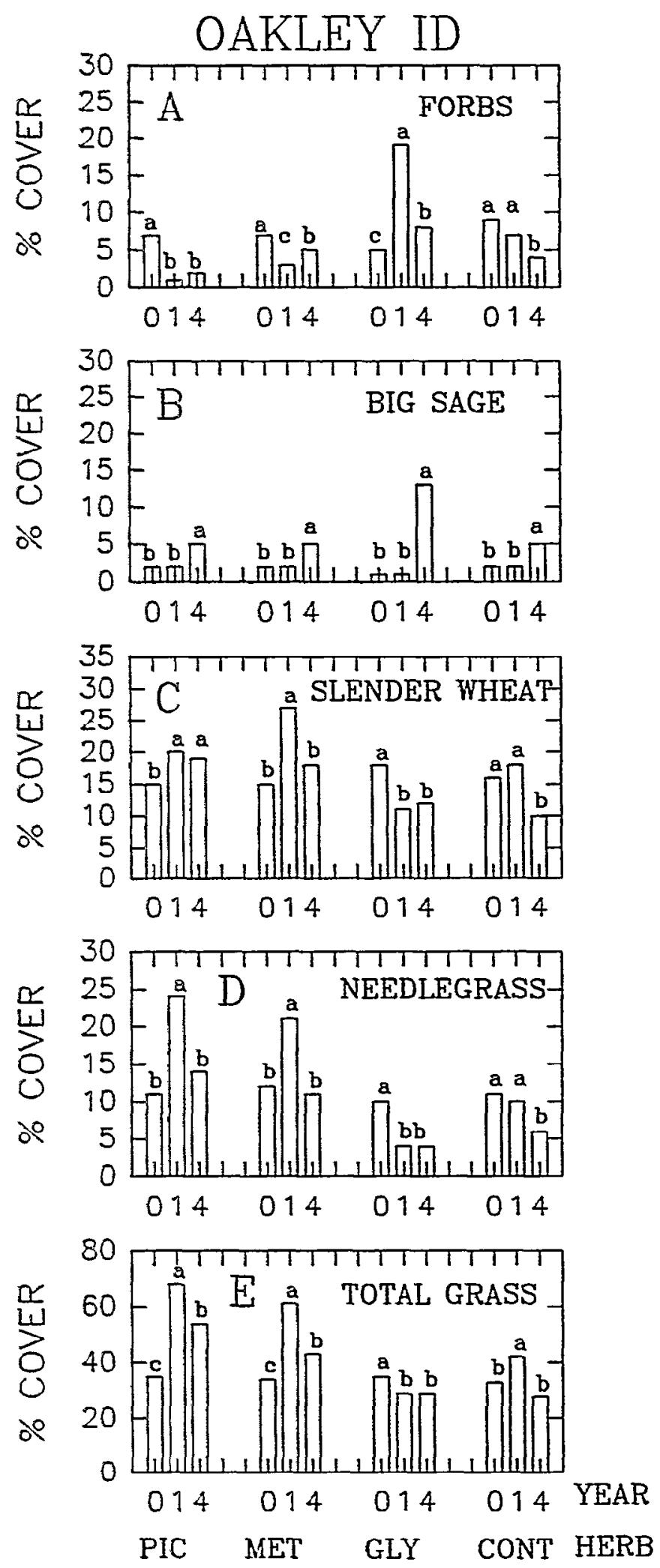

Fig. 1. Percentage foliar cover of species at Oakley Ida. PIC = piclorem, MET = metsulfuron, GLY = glyphosate, CONT = untreated control. Within each herbicide treatment, bars having different letters are significantly different $(P<0.05)$.
(Elymus cinereus Scribn \& Merr). Total grass cover is important from a forage standpoint, as well as the fiberous root system preventing erosion. Total grass cover doubled in year 1 on plots treated with picloram and metsulfuron (68 and $61 \%$ respectively), but declined by the end of the study (Fig. 1e). The picloram treatments, and metsulfuron at $0.14 \mathrm{~kg} / \mathrm{ha}$, maintained total grass cover about $50 \%$ at the end of the study, while total grass cover on glyphosate and control plots averaged only $30 \%$.

Bare ground increased in all treatments in year 1 (data not shown). Bare ground doubled by the end of the study on the untreated check plots (33\%) as a result of the prolonged drought. Glyphosate treatments maintained higher amounts of bare ground (42\%) than the untreated check, but bare ground on the picloram and metsulfuron plots was not significantly different from the untreated check (37\%).

\section{Manti}

Forbs declined in all treatments (Fig. 2a). However, the decline was less in the glyphosate treatments, and forb cover on the glyphosate plots was greater than on the untreated control plots at the end of the study. Lambsquarter (Chenopodium album L) dominated the forb component on the glyphosate plots in the first year, and Senecio (Senecio crassulus Gray), common dandelion (Taraxacum officinale Weber ex. Wiggers), and lupine (Lupinus argenteus Pursh) were dominant at the end of the study.

Herbaceous sage (Artemisia michauxiana Basser), a rhizomatous forb, was also present on the site. Picloram and metsulfuron reduced herbaceous sage cover the first year to 1-2\%, but it returned to pretreatment levels at the end of the study (Fig. 2b). Herbaceous sage remained the same in glyphosate plots in year 1 (7\%), but increased to $15 \%$ at the end of the study. There was also a corresponding increase of herbaceous sage in the untreated check plots. Herbaceous sage was greater in all treatments when sprayed in larkspur's flower stage due to its herbicide resistance in the later growth stages.

Grass cover was lower at Manti than at Oakley. Mountain brome doubled in the plots treated with metsulfuron, and remained about $10 \%$ of the total cover at the end of the study (Fig. 2c). Brome increased in the plots treated with picloram at $1.1 \mathrm{~kg} / \mathrm{ha}$ (19\%), but declined in the $4.5 \mathrm{~kg} / \mathrm{ha}$ treatment to $3 \%$. High rates of picloram appear to be detrimental to brome. Glyphosate did not reduce cover of brome; however, brome did not increase as it did in other treatments. Brome was least affected by glyphosate when sprayed early in larkspurs' vegetative stage (data not shown).

Letterman needlegrass cover increased to $10 \%$ in plots treated with picloram (Fig. 2d), and remained high (14\%) in the 4.5 $\mathrm{kg} / \mathrm{ha}$ treatment. Letterman needlegrass appears to be resistant to high levels of picloram. Its cover increased in plots treated with metsulfuron (8\%), but declined to pretreatment levels at the end of the study (4\%). Letterman needlegrass remained about the same after 1 year in plots treated with glyphosate, but declined by the end of the study ( $2 \%$ ), as it did in the untreated control plots (Fig. 2d).

Other grasses on site included slender wheatgrass, Kentucky bluegrass and meadow barley (Hordeum brachyantherum Nevski). Cover of total grasses increased in plots treated with picloram in year 1 (Fig. 2e), and continued to increase by the end of the study to $29 \%$. Metsulfuron treatements allowed total grass cover to increase in year 1 , and it remained relatively constant at the end of the study (21\%). Total grass cover remained fairly 

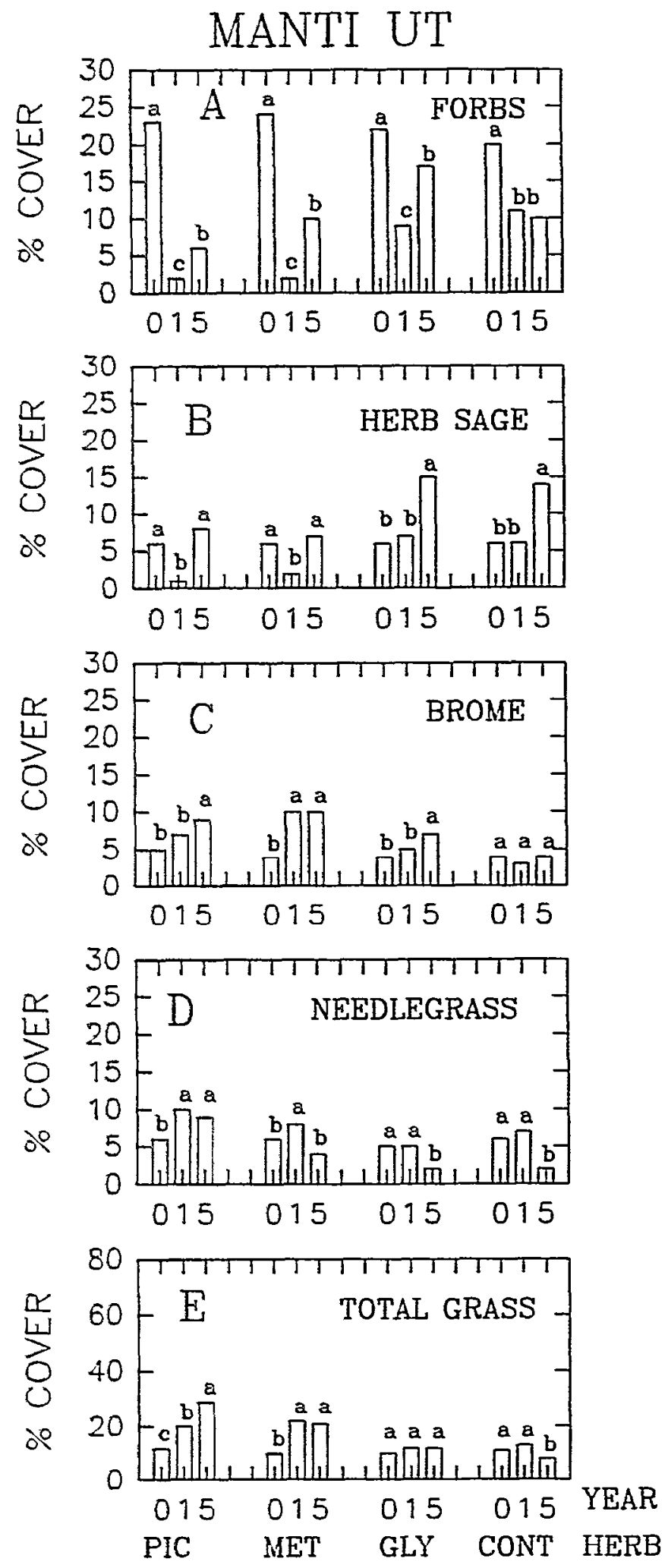

Fig. 2. Fercentage foliar cover of species at Manti Utah. PIC = picloram, MET = metsulfuron, $\mathrm{GLY}=$ glyphosate, $\mathrm{CONT}=$ untreated control. Within each herbicide treatment, bars having different letters are significantly different $(P<0.05)$. constant in the glyphosate treatments over the study (12\%).

Bare ground increased the first year after treatment (50-77\%). It declined by the end of the study as other vegetation filled in, but the herbicide treated plots still had more bare ground (39-53\%) than the untreated check plots (29\%).

\section{Discussion}

Duncecap larkspur was susceptible to picloram, metsulfuron, and glyphosate when sprayed in the vegetative stage. Low rates of the herbicides were less effective on tall larkspur in the vegetative stage. The cooler temperatures early in the growing season at the higher elevation at Manti may have contributed to the reduced efficacy of the lower rates of the herbicides. We would expect tall larkspur at lower elevations to respond similar to duncecap larkspur. The higher rates of all herbicides tested were equally effective, giving near total control of both larkspur species when sprayed in larkspurs' vegetative stage.

Metsulfuron initially controlled both larkspur species when applied in the vegetative stage. Efficacy dropped off drastically when applied in later growth stages of both species. The lower application rates $(0.035$ to $0.07 \mathrm{~kg} / \mathrm{ha})$ maintained near total control of duncecap larkspur after 3 to 5 years. However, new tall larkspur seedlings established on metsulfuron plots at Manti. Bunderson et al. (1995) also reported that new seedlings established on metsulfuron plots in the Manti area.

We can only speculate as to why tall larkspur seedlings established following treatment with metsulfuron and not the other herbicides. Growing season precipitation was $70 \%$ greater at Manti than at Oakley. The climatic pattern at Manti is characterized by summer thunder storms, while Oakley is characterized by summer drought. In addition, the prolonged drought at Oakley apparently decreased the larkspur population, let alone allowing new larkspur seedlings to become established. Grass cover on metsulfuron plots at Oakley was also very high the first year after treatment. Perhaps competition form grasses contributed to the lack of reestablishment.

Picloram has a long half-life $(12 \mathrm{mo})$ and is slowly degraded by soil microbes, especially in cooler temperatures at this high altitude. Residue of picloram in the top $2.5 \mathrm{~cm}$ of soil was 300 to $800 \mathrm{ppb}$ the year after treatment on an adjacent study (Evans et al. 1993). The residual effects of picloram in soil may have prevented establishment of tall larkspur seedlings. The low amount of metsulfuron applied, coupled with its short half-life (45 days) produced residues of only 1 to $2 \mathrm{ppb}$. The lack of residual activity may have allowed larkspur seedlings to establish. Glyphosate adheres tightly to soil organic matter and would not likely have any residual effects. Perhaps the greater cover of forbs and herbaceous sage on glyphosate plots provided sufficient competition to prevent establishment of tall larkspur seedlings.

Picloram at $2.2 \mathrm{~kg} / \mathrm{ha}$ controlled both species of larkspur when applied throughout the growing season. The high rate of picloram ( $4.5 \mathrm{~kg} . \mathrm{ha})$ was detrimental to slender wheatgrass at Oakley and brome at Manti. However, total grass cover was higher on picloram plots than on plots treated with other herbicides. Picloram treatments had the highest amount of bare ground at Manti after 5 years (53\%). Bare ground on picloram plots did not differ from that on the untreated check plots at Oakley.

Glyphosate at $1.1 \mathrm{~kg} / \mathrm{ha}$ was effective in killing duncecap lark- 
spur, and $2.2 \mathrm{~kg} / \mathrm{ha}$ killed tall larkspur. Its efficacy was also greater in the vegetative and bud stage. Glyphosate is non-selective and significantly reduced desirable forbs at both locations and grasses at Oakley. Brome was not adversely affected by glyphosate, but it did not increase as in the other herbicide treatments. Weedy annuals and rhizomatous perennial forbs dominated glyphosate plots. The higher amounts of bare ground also allowed big sagebrush to increase at Oalley and herbaceous sage to increase at Manti. Bare ground was greater on plots treated with glyphosate than on the untreated check plots at the end of the study at both Oakley and Manti. Glyphosate can be applied as a spot spray to kill both larkspur species without harming associated regetation (Ralphs et al. 1991). It can also be applied with a carpeted roller applicator (Bunderson et al. 1995).

Grazing undoubtedly had an impact on the long term response of the vegetation. Both sites were grazed by cattle. Cronin (1976) reported that brome increased markedly on ungrazed plots following treatment with 2,4,5-T [(2,4,5-trichlorophenoxy) acetic acid], while slender wheatgrass and Letterman needlegrass increased on grazed plots. Brome increased the first year after treatment at Manti in our study, but remained about the same at the end of the study. Perhaps grazing restricted further increases in cover of brome. Letterman needlegrass in our study responded similar to Cronin's study. It increased during the first year after treatment, then declined over time. Cronin suggested that desirable grasses (brome and slender wheatgrass) could be enhanced by resting treated pastures the year of treatment, and by late season grazing thereafter.

\section{Management Recommendations}

Metsulfuron at 0.035 or $0.07 \mathrm{~kg} / \mathrm{ha}$ will effectively control duncecap larkspur if applied when duncecap larkspur is in the regetative growth stage. Metsulfuron is least environmentally harmful from the standpoint of low application rates, short halflife, exposing bare ground, and increasing grass cover. Picloram at 1.1 or $2.2 \mathrm{~kg} / \mathrm{ha}$ was generally effective in controlling both larkspur species throughout the growing season. This provides an advantage since many populations of larkspur at high elevations are inaccessible early in the growing season. Glyphosate at 2.2 $\mathrm{kg} / \mathrm{ha}$ was effective in the vegetative and bud stage. It is nonselective and will damage other vegetation, so it must be selectively applied to larkspur plants.

\section{Literature Cited}

Bunderson, F.B., M.H. Ralphs, J.O. Evans, C.A. Call, and D.B. Nielsen. 1995. A comparison of herbicide application methods for larkspur (Delphinium spp.) control on high elevation rangelands. Weed Technol. (in press).

Cronin, E.H. 1976. Impact on associated vegetation of controlling tall larkspur. J. Range Manage. 29:202-206.

Cronin, E.H. and D.B. Nielsen. 1979. Ecology and control of rangeland larkspurs. Utah Agr. Exp. Sta. Bull 499.

Ellison, L. 1954. Subalpine vegetation of the Wasatch Plateau, Utah. Ecol. Monogr. 24:89-184.

Evans, J.O., M.H. Ralphs, and F.B. Bunderson. 1993. Assessment of herbicide residues in soil and water from larkspur control on high elevation watersheds. West. Soc. Weed Sci. Prog. Rep.

Mickelsen, L.V., M.H. Ralphs, D.L. Turner, J.O. Evans and S.A. Dewey. 1990. Herbicidal control of duncecap larkspur (Delphinium occidentale). Weed Sci. 38:153-157.

Nielsen, D.B., M.H. Ralphs, J.O. Evans and C.A. Call. 1994. Economic feasibility of controlling tall larkspur on rangelands. J. Range Manage. 47:369-372.

Ralphs, M.H., L.V. Mickelsen, J.O. Evans and S.A. Dewey. 1991. Selective application of glyphosate for control of larkspurs (Delphinium spp.). Weed Technol. 5:229-231.

Ralphs, M.H., J.O. Evans, and S.A. Dewey. 1992. Timing of herbicide applications for control of larkspurs (Delphinium spp). Weed Sci. 40:264-269. 